\title{
THE PALAEOZOIC PELECYPOD FAMILY RHOMBOPTERIIDAE AND THE EVOLUTION OF THE OSTREINA
}

JOHNSTON*, Paul A., Royal Tyrrell Museum of Palaeontology, Box 7500, Drumheller, Alberta, TOJ 0Y0, Canada.

Though long suspected to be critical to the understanding of the evolution of the pelecypod subclass Pteriomorphia, the mid-Palaeozoic family Rhombopteriidae was too poorly known to allow clarification of its relationships. Furthermore, numerous species were assigned to the nominate genus, Rhombopteria, many of which belong in other genera or even other subclasses. Consequently, the morphologic concept entailed by Rhombopteria was confused as were functional morphologic investigations.

Silicified rhombopteriids discovered in the Lower Devonian of Australia are referred to a new genus, and reveal internal shell characters essential for understanding rhombopteriid relationships. The family Rhombopteriidae is revised to include only three genera, Rhombopteria, Prantliella and the new Australian genus.

New data provided by the Australian material indicate that rhombopteriids were non-byssate, dimyarian pteriomorphs that lived pleurothetically on the left valve as do gryphaeid oysters. The Rhombopteriidae are assigned to the Ostreina and are the sister group of all other ostreinans including the Ostreoidea, Pseudomonotidae and Terquemiidae. Important characters common to rhombopteriids and gryphaeid oysters include: 1) left-sided pleurothetic habit; 2) absence of byssal notch or sinus throughout ontogeny; 3) Quenstedt muscle scar; 4) proximal gill weal; 5) circumferential curb; 6) commissural shelf; and 7) posteroventral palliobranchial fusion as evidenced by a branchitellum and posterior radial fold and sulcus. Outgroup comparison with Umburridae indicate that characters 1-4 are symplesiomorphic for the Order Ostreoida. Characters 5-7 are autapomorphies for a clade including the Rhombopteriidae, Pseudomonotidae, Terquemiidae and Ostreoidea.

Rhombopteriids were probably derived from left-sided pleurothetic, umburridlike ancestors which, in turn, descended from primitive, equivalved, orthothetic prionodonts. Thus, a right-sided pleurothetic stage was never part of the evolutionary pathway of oysters. The inequivalved shell of eupteriomorphs evolved initially for a left-sided pleurothetic semi-infaunal habit. Retained as an adaptation in rhombopteriids and oysters, the inequivalved shell is an exaptation in Pterioida (winged shells), Pectinina (scallops) and Pseudomonotidae, having been coopted for a right-sided pleurothetic orientation, and having the effect of enhancing stability in an epifaunal habit. Evolution of right-sided pleurothetic pteriomorphs, including the Pseudomonotidae, Pectinina and Pterioida, from separate left-sided pleurothetic rhombopteriid-like or umburrid-like ancestors, is explicable by paedomorphic retention of the byssus and epifaunal habit of the early post-larva. A right-sided pleurothetic orientation would follow 'automatically' owing to hydrodynamic and mechanical constraints on the already evolved, inequivalved shell, byssally attached by the anterior margin on the substrate surface. 